\title{
PENGARUH LINGKUNGAN KELUARGA DAN LINGKUNGAN SEKOLAH TERHADAP KEDISIPLINAN SISWA
}

\author{
Afrida Nesya Putri ${ }^{1}$, Nastiti Mufidah ${ }^{2}$ \\ 1Institut Agama Islam Negeri Ponorogo \\ afnesyaa@gmail.com \\ ${ }^{2}$ Institut Agama Islam Negeri Ponorogo \\ nastiti@iainponorogo.ac.id
}

\begin{abstract}
ABSTRAK
Penelitian ini bertujuan untuk mengetahui apakah lingkungan keluarga berpengaruh secara signifikan terhadap kedisiplinan siswa kelas IX di SMP Negeri 1 Magetan tahun pelajaran 2020/2021, untuk mengetahui apakah lingkungan sekolah berpengaruh secara signifikan terhadap kedisiplinan siswa kelas IX di SMP Negeri 1 Magetan tahun pelajaran 2020/2021 dan untuk mengetahui apakah lingkungan keluarga dan lingkungan sekolah berpengaruh secara signifikan terhadap kedisiplinan siswa kelas IX di SMP Negeri 1 Magetan tahun pelajaran 2020/2021. Metode penelitian kuantitatif digunakan dalam penelitian ini dengan jenis penelitian ex-post facto dan teknik pengumpulan data yaitu angket dan dokumentasi. Pada penelitian ini populasi berjumlah 339 siswa dan sampel berjumlah 85 dengan menggunakan teknik sampling yaitu purposive sampling. Dari hasil penelitian ditemukan, bahwa lingkungan keluarga berpengaruh secara signifikan terhadap kedisiplinan siswa sebesar 35,3\% dan 64,7\% sisanya dipengaruhi oleh faktor lain, lingkungan sekolah berpengaruh secara signifikan terhadap kedisiplinan siswa sebesar 32,3\% dan 67,7\% sisanya dipengaruhi oleh faktor lain serta lingkungan keluarga dan lingkungan sekolah berpengaruh secara signifikan terhadap kedisiplinan siswa sebesar $47,4 \%$ dan $52,6 \%$ sisanya dipengaruhi oleh faktor lain.
\end{abstract}

Kata kunci: Lingkungan keluarga; Lingkungan sekolah; Kedisiplinan siswa

\section{ABSTRACT}

This study aims to determine whether the family environment significantly influences 
the discipline of grade IX students at SMP Negeri 1 Magetan in the 2020/2021 academic year, to find out whether the school environment significantly influences the discipline of grade IX students at SMP Negeri 1 Magetan in the 2020/2021 academic year. and to find out whether the family environment and school environment significantly influence the discipline of class IX students at SMP Negeri 1 Magetan for the 2020/2021 school year. Using quantitative research methods with the type of ex-post facto research and data collection techniques, namely questionnaires and documentation. In this study a population of 339 students and a sample of 85 using a sampling technique, namely purposive sampling. From the results of the study it was found that the family environment had a significant effect on student discipline by $35.3 \%$ and the remaining 64.7\% was influenced by other factors, the school environment had a significant effect on student discipline by $32.3 \%$ and the remaining $67.7 \%$ was influenced by by other factors and the family environment and school environment significantly influence student discipline by $47.4 \%$ and the remaining $52.6 \%$ is influenced by other factors.

Keywords: Family environment; School environment; Student discipline

\section{PENDAHULUAN}

Dalam proses pendidikan, umumnya suatu kedisiplinan harus dimiliki oleh siswa, baik itu saat proses pembelajaran maupun di luar pembelajaran. Kedisiplinan harus dikedepankan pada pendidikan, seseorang yang memiliki ciri-ciri disiplin adalah produk dari proses pendidikan. Setiap individu memiliki kedisiplinan yang berbeda-beda, baik itu disiplin hasil belajar, disiplin sikap dan disiplin perbuatan. Adapun faktor yang dapat mempengaruhi kedisiplinan siswa yaitu faktor intern dan ekstern. Faktor intern ialah faktor yang berasal dalam diri siswa, sedangkan faktor ekstern berasal dari luar diri siswa yakni lingkungan keluarga dan lingkungan sekolah. Faktor dari dalam yakni berupa kesadaran diri. Sedangkan faktor yang berasal dari luar diri siswa yaitu pengaruh lingkungan, seperti lingkungan keluarga, lingkungan sekolah dan lingkungan masyarakat. ${ }^{1}$

Lingkungan keluarga merupakan wadah untuk anak dalam menumbuhkan karakterdisiplin. Peran anggotakeluargasangatberpengaruhterhadapkedisiplinan anak. Orang tua adalah sosok yang bertanggung jawab dalam menumbuhkan karakter anak, terutama pada sikap disiplin. Anak dengan mudah menerima apa yang dilihat dan didengar dari orang tuanya akan dijadikan sebagai pedoman utama dalam berperilaku di luar lingkungan keluarga. Siswa merupakan subjek serta objek dari pendidikan dalam bimbingan orang lain untuk mengarahkan, mengembangkan potensi siswa serta membimbing menuju sikap yang dewasa. Jadi, siswa adalah orang yang membutuhkan pengembangan disiplin melalui

1 Kompri. Belajar Dan Faktor-Faktor Yang Mepengaruhinya. Media Akad:Yogyakarta, 2017. 240. 
usaha orang dewasa agar bisa mencapai kesempurnaan manusia. ${ }^{2}$ Motivasi dalam diri siswa menjadi salah satu faktor yang dapat mendukung pembentukkan sikap disiplin individu serta dilengkapi oleh dukungan dari pihak lain yang ada di lingkungan siswa tersebut.

Kedisiplinan sebagai kondisi yang tercipta dan terbentuk dengan melalui berbagai proses serta perilaku yang bernilai seperti, taat, patuh, setia dan teratur atau tertib. Siswa dikatakan disiplin jika siswa tersebut telah melakukan suatu hal yang sesuai dengan peraturan atau tata tertib yang ada di sekolah dan tidak melanggarnya. Lingkungan sekolah yang teratur, tertib dan tenang dapat mendukung siswa lebih giat, gigih, serius, penuh perhatian dan kompetitif dalam kegiatan belajarnya. Disiplin di sekolah jika dikembangkan dan dapat diterapkan secara konsisten dan konsekuan, maka akan memberikan dampak yang positif bagi perilaku dan pola kehidupan siswa.

Menurut Rachman, kedisiplinan sangat penting bagi siswa karena untuk: (1) Mendukung siswa supaya perilakunya selalu baik, (2) Membantu siswa dalam memahami dan menyesuaikan diri dengan tuntunan lingkungan, (3) Menyelesaikan tuntunan bagi siswa terhadap lingkungannya, (4) Mengantar kesesuaian siswa terhadap keinginannya dengan yang lain, (5) Melarang siswa atas hal-hal yang tidak ada pada peraturan sekolah, (6) Mendukung siswa melakukan kebaikan dan kebenaran, (7) Siswa dapat belajar, kemudian akan bermanfaat baginya dan lingkungan, (8) Kebiasaan-kebiasaan yang baik menyebabkan jiwanya tenang dengan lingkungannya. ${ }^{3}$

Disiplin erat kaitannya dengan peraturan atau tata tertib yang ada di sekolah. Di sekolah, peraturan bertujuan untuk menjamin kehidupan dengan penuh ketertiban dan ketenangan. Disiplin di sekolah adalah kewajiban dari seluruh warga sekolah guna tercapainya tujuan dari sekolah tersebut. Nyatanya, masih sering terjadi sebuah pelanggaran pada peraturan di sekolah. Maka, guru dituntut dapat memberikan tauladan dalam bersikap dan bertindak yang baik sesuai dengan aturan dan etika moral yang baik, karena semua yang dilihat siswa itulah yang akan ditiru siswa tersebut. Dengan adanya tata tertib di sekolah, diharapkan supaya siswa dapat memahami sebuah ketertiban dan dapat hidup selaras di lingkunganya. Sekolah menerapkan tata tertib supaya siswa dapat mematuhi tuntutan pada proses pendidikan. Di dalam lingkungan sekolah, kedisiplinan berperan sangat penting bagi siswa. Sikap disiplin siswa di sekolah sangatlah diperlukan, karena kedisiplinan akan menghasilkan sebuah karya yang diharapkan.

2 Kompri. 237.

3 Yuliastuti dan Rian Vebrianto. Pengaruh Lingkungan Negatif Terhadap Kedisiplinan Siswa SD Negeri 134 Pekanbaru. Natural Science and Integratio, 2018: 223. 
Dari penjelasan di atas, dapat disimpulkan bahwa lingkungan keluarga dan lingkungan sekolah memiliki pengaruh terhadap kedisiplinan siswa. Lingkungan keluarga dengan proses bimbingan yang tepat dapat membentuk kepribadian pada anak menjadi lebih baik. Begitu juga dengan lingkungan sekolah yang memiliki tingkat kedisiplinan yang baik serta tata tertib yang tepat, sehingga kedisiplinan siswa dapat berkembang dengan baik juga.

Menurut Tulus Tu'u, ada tujuh hal pelanggaran disiplin yang dapat terjadi, yaitu sebagai berikut: (1) Sekolah kurang merencanakan dalam kedisiplinan yang baik, (2) Ketika memiliki rencana yang baik, namun dalam implementasi dan monitoring dari kepala sekolah kurang baik, (3) Dalam menerapkan kedisiplinan tidak konsekuen dan konsisten, (4) Kebijakan dari kepala sekolah yang belum diprioritaskan terkait kedisiplinan di sekolah, (5) Kurangnya kebersamaan atau gotong royong dan support dari guru ketika merencanakan dan mengimplementasikannya pada kedisiplinan di sekolah, (6) Partisipasi dan dukungan dari orang tua yang kurang dalam menangani permasalahan terkait disiplin di sekolah, khususnya pada siswa yang memiliki masalah, (7) Di sekolah, berbagai siswa berasal dari siswa yang memiliki masalah dalam sikap disiplin yang ada pada diri siswa. Siswa akan cenderung melakukan pelanggaran dan mengabaikan peraturan yang ada di sekolah. ${ }^{4}$

Berdasarkan berbagai permasalahan yang telah dibahas pada paragraf sebelumnya, tujuan dari penelitian ini adalah: untuk mengetahui apakah lingkungan keluarga berpengaruh secara signifikan terhadap kedisiplinan siswa kelas IX di SMP Negeri 1 Magetan tahun ajaran 2020/2021, untuk mengetahui apakah lingkungan sekolah berpengaruh secara signifikan terhadap kedisiplinan siswa kelas IX di SMP Negeri 1 Magetan tahun ajaran 2020/2021 dan untuk mengetahui apakah lingkungan keluarga dan lingkungan sekolah berpengaruh secara signifikan terhadap kedisiplinan siswa kelas IX di SMP Negeri 1 Magetan tahun ajaran 2020/2021.

Manfaat penelitian ini secara teoritis, dapat menambah khazanah ilmu pengetahuan bagi peneliti pendidikan, khususnya pada sikap disiplin siswa dan dapat dijadikan dasar bagi penelitian yang akan datang. Secara praktis, bagi guru dapat memberikan sumber pengetahuan dan informasi dalam mengajar dan mendidik serta mengarahkan siswa pada kedisiplinannya. Bagi penulis untuk menambah pengetahuan dan pengalaman dalam penelitian yang terkait dengan adanya kedisiplinan siswa yang dipengaruhi oleh lingkungan keluarga dan lingkungan sekolah.

4 Tulus Tu'u, Peran Disiplin Pada Perilaku Dan Prestasi Siswa. Jakarta: PT Grasindo. 2020. 53 . 


\section{METODE PENELITIAN}

Penelitian ini menggunakan pendekatan kuantitatif dengan metode penelitian berfilsafat postpositivisme, yakni penelitian yang digunakan untuk meneliti suatu populasi dan sampel tertentu. Populasi dari penelitian ini adalah seluruh siswa kelas IX di SMP Negeri 1 Magetan yang berjumlah 399 siswa. Karena populasi lebih dari 100, maka sampel dalam penelitian ini berjumlah 85 siswa dengan menggunakan teknik pengambilan sampel yakni purposive sampling. Teknik pengumpulan data dalam penelitian ini yaitu menggunakan kuesioner (angket) dan dokumentasi. Kuesioner pada penelitian ini mengacu pada skala likert dengan data lingkungan keluarga (X1), lingkungan sekolah (X2) dan kedisiplinan siswa (Y). Dokumentasi berupa data siswa yang menjadi obyek penelitian yakni, sejarah berdirinya sekolah, visi dan misi, struktur organisasi, keadaan guru, dan data-data yang diperlukan di SMP Negeri 1 Magetan.

Dalam penelitian ini, teknik analisis data menggunakan statistika dengan program SPSS 23.0. Tahap pra penelitian, uji validitas memiliki tujuan dalam mengetahui item-item soal yang diuji coba, apakah dapat digunakan untuk mengukur keadaan responden dengan sebenarnya dan uji reliabilitas, menurut Hasan dan Malhotra, reliabilitas adalah tingkatan dimana suatu pengukuran yang dilakukan berulang-ulang kali dan memberikan hasil yang konsisten. Instrumen dapat dikatakan reliabel, apabila alat ukur memberikan hasil dengan konsisten atau ajeg. ${ }^{5}$

Peneliti melakukan uji asumsi klasik atau uji pra syarat supaya ketika menggunakan rumus dapat memberikan hasil yang tidak menyimpang. Uji asumsi meliputi, uji normalitas, uji linieritas, uji multikolinieritas dan uji heteroskedastisitas yang diuraikan seperti di bawah ini: (1) Uji normalitas yaitu uji normal pada distribusi sebuah data. ${ }^{6}$ Dapat dikatakan normal atau tidak, yakni dengan cara membandingkan nilai signifikansi 0,05. (2) Uji linieritas digunakan untuk menganalisis regresi linier sederhana dan regresi linier berganda. Pada uji ini dapat dilakukan dengan cara mencari model garis regresi variabel bebas (X) terhadap variabel terikat $(\mathrm{Y})$, sehingga model regresi tersebut, dapat diuji kelinieritasan garis regresinya. (3) Menurut Ghozali, uji multikolinieritas dapat digunakan untuk mengetahui apakah ada hubungan atau korelasi antara variabel bebas atau variabel independen. Ada tidaknya gejala multikolinieritas dapat diketahui jika nilai VIF $<10$ maka tidak terjadi gejala multikolinieritas.

5 Tulus Tu'u. 128.

6 Andhita Dessy Wulansari. Statistika Parametrik Terapan Untuk Penelitian Kuantitatif. Ponorogo: STAIN Po Press. 2016. 38.

7 Ibid. 55. 
Begitu sebaliknya, jika nilai VIF > 10 maka mengalami gejala multikolinieritas. ${ }^{8}$ (4) Uji heteroskedastisitas merupakan alat uji model regresi untuk mengetahui ketidaksamaan nilai variance dari residual satu pengamatan ke pengamatan lainnya. Jika nilai variance dari residual tetap, maka disebut homokedastisitas dan jika berbeda disebut heteroskedastisitas. ${ }^{9}$ (5) Uji autokorelasi memiliki tujuan untuk menguji apakah dalam suatu model regresi linier terdapat korelasi antar kesalahan pengganggu (residual) pada periode $\mathrm{t}$ dengan kesalahan pada periode i-1 sebelumnya. Suatu model regresi dinyatakan tidak terdapat permasalahan autokorelasi apabila, du $<\mathrm{d}<4-\mathrm{du} .{ }^{10}$

Setelah peneliti melakukan perhitungan dari beberapa uji asumsi klasik, kemudian tahap selanjutnya yakni uji hipotesis. Uji hipotesis ini berguna dalam menjawab rumusan masalah pada penelitian. Adapun langkah-langkah dalam pengujian hipotesis dengan uji regresi linier sederhana dan uji regresi linier berganda yang diuraikan sebagai berikut: (1) Peneliti menggunakan uji regresi linier sederhana, karena dapat digunakan dalam mencari adanya suatu pola hubungan antara satu variabel terikat dengan satu variabel bebas. ${ }^{11}(2) \mathrm{Uji}$ regresi linier berganda dengan dua variabel dapat digunakan untuk mencari adanya pola hubungan antara satu variabel terikat dengan $>$ satu variabel bebas. ${ }^{12}$

\section{HASIL DAN PEMBAHASAN}

\section{Hasil}

Lingkungan keluarga berpengaruh secara signifikan terhadap kedisiplinan siswa kelas IX di SMP Negeri 1 Magetan dengan dibuktikan hasil seperti di bawah ini:

8 Haslinda dan Jamaluddin M. Pengaruh Perencanaan Anggaran Dan Evaluasi Anggaran Terhadap Kinerja Organisasi Dengan Standar Biaya Sebagai Variabel Moderating Pada Pemerintah Daerah Kabupaten Wajo. Jurnal Ilmiah Akuntansi Peradaban 1. 2016: 8.

9 Echo Perdana K. Olah Data Skripsi Dengan SPSS 22. Bangka Belitung: LAB KOM Manajemen FE UBB. 2016:49.

10 Dyah Nirmala Arum Janie. Statistik Deskripstif \& Regresi Linier Berganda Dengan SPSS. Semarang:University Press Semarang. 2012:30.

11 Andhita Dessy Wulansari. Statistika Parametrik. 122.

12 Andhita Dessy Wulansari. 122. 
Tabel 1. Tabel anova regresi linier sederhana X1 dan Y

\begin{tabular}{|c|c|c|c|c|c|}
\hline \multicolumn{6}{|c|}{$A N O V A^{a}$} \\
\hline \multirow[b]{2}{*}{ Model } & Sum & of & Mean & & \\
\hline & Squares & $D f$ & Square & $F$ & Sig. \\
\hline $\begin{array}{ll}1 & \text { Regressio } \\
n\end{array}$ & 443.170 & 1 & 443.170 & 45.250 & $.000^{b}$ \\
\hline Residual & 812.877 & 83 & 9.794 & & \\
\hline Total & 1256.047 & 84 & & & \\
\hline
\end{tabular}

\section{Tabel 2. Tabel model summary regresi linier sederhana X1 dan $\mathrm{Y}$}

\section{Model Summary}

\begin{tabular}{llrrr}
\hline Model & $R$ & $R$ Square & Adjusted R Square & $\begin{array}{c}\text { Std. Error of the } \\
\text { Estimate }\end{array}$ \\
\hline 1 & $.594^{a}$ & .353 & .345 & 3.12949 \\
\hline a. Predictors: (Constant), Lingkungan Keluarga
\end{tabular}

Dari hasil perhitungan pada peneliti ini, dengan menggunakan rumus regresi linier sederhana diketahui fhitung berjumlah 45,250 selanjutnya dibandingkan dengan ftabel dan taraf signifikan 0,5 yakni: 3,96 maka dapat diperoleh fhitung $>$ ftabel maka Ho1 ditolak, sehingga lingkungan keluarga ada pengaruh terhadap kedisiplinan siswa. Berdasarkan hasil perhitungan koefisiens determinasi $\left(\mathrm{R}^{2}\right)$, memperoleh nilai 35,3\% yang berarti lingkungan keluarga berpengaruh secara signifikan terhadap kedisiplinan siswa kelas IX di SMP Negeri 1 Magetan dan sisa $64,7 \%$ dipengaruhi dari faktor lain.

Menurut Syamsu Yusuf, keluarga adalah sebuah buaian bagi masyarakat masa depan dan di lingkungan keluarga menjadi faktor penentu yang sangat berpengaruh terhadap kualitas generasi mendatang. Keluarga memiliki fungsi sebagai miniatur masyarakat yang dapat bersosialisasi dengan nilai atau peran hidup dalam bermasyarakat yang dilaksanakan oleh anggota-anggotanya. Keluarga dapat diartikan sebagai lembaga yang dapat mempengaruhi perkembangan kemampuan individu dalam mentaati peraturan atau sikap disiplin, dapat bekerja sama, bersikap toleran, menghargai pendapat orang lain, bertanggung jawab dan bersikap lebih dewasa dalam kehidupan yang heterogen (etnis, rasa, budaya dan agama). ${ }^{13}$

13 Syamsu Yusuf. Psikologi Perkembangan Anak Dan Remaja. Bandung: PT Remaja Rosdakarya, 2009. 40-41. 
Lingkungan sekolah berpengaruh secara signifikan terhadap kedisiplinan siswa kelas IX di SMP Negeri 1 Magetan dengan dibuktikan hasil seperti di bawah ini:

Tabel 3. Tabel anova regresi linier sederhana X2 dan $Y$

\begin{tabular}{llllll}
\multicolumn{6}{c}{ ANOVA $^{\boldsymbol{a}}$} \\
\hline Model & $\begin{array}{l}\text { Sum of } \\
\text { Squares }\end{array}$ & Df & Mean Square & $F$ & Sig. \\
\hline $\begin{array}{l}\text { Regressi } \\
\text { on }\end{array}$ & 405.789 & 1 & 405.789 & 39.61 & $.000^{b}$ \\
Residual & 850.258 & 83 & 10.244 & 2 & \\
Total & 1256.047 & 84 & & & \\
\hline a. Dependent Variable: Kedisiplinan Siswa & \\
b. Predictors: (Constant), Lingkungan Sekolah & &
\end{tabular}

Tabel 4. Tabel model summary regresi linier sederhana X2 dan $\mathrm{Y}$

\begin{tabular}{llccc}
\hline \multicolumn{4}{c}{ Model Summary } \\
\hline Model & $R$ & $R$ Square & $\begin{array}{c}\text { Adjusted } R \\
\text { Square }\end{array}$ & $\begin{array}{c}\text { Std. Error of the } \\
\text { Estimate }\end{array}$ \\
\hline 1 & $.568^{a}$ & .323 & .315 & 3.20064 \\
\hline a. Predictors: (Constant), Lingkungan Sekolah
\end{tabular}

Dari hasil perhitungan yang dilakukan peneliti terkait pengaruh lingkungan sekolah terhadap kedisiplinan siswa kelas IX menggunakan rumus regresi linier sederhana diketahui fhitung berjumlah 39,612 selanjutnya dibandingkan dengan ftabel dan taraf signifikan 0,5 yakni: 3,96 maka dapat diperoleh fhitung > ftabel maka Ho2 ditolak, sehingga lingkungan sekolah berpengaruh secara signifikan terhadap kedisiplinan siswa. Berdasarkan hasil perhitungan koefisien determinasi $\left(\mathrm{R}^{2}\right)$, yang bernilai 32,3\% memiliki arti bahwa lingkungan sekolah berpengaruh terhadap kedisiplinan siswa kelas IX di SMP Negeri 1 Magetan dan $67,7 \%$ dari sisa tersebut dapat dipengaruhi faktor yang lainnya.

William Bennett mengatakan bahwa, sekolah memiliki peran penting yang berkaitan dalam pengembangan pendidikan karakter siswa. Bahkan pada siswa yang tidak mendapatkan pendidikan karakter sama sekali di lingkungan bahkan di dalam keluarganya. Di sekolah, memiliki pengaruh yang sangat besar bagi kepribadian siswa ketika siswa merekam semua apa yang ada di memorinya sampai tumbuh menjadi dewasa. Sekolah merupakan salah satu wadah efektif 
internalisasi pendidikan karakter terhadap siswa. ${ }^{14}$ Kompri mengemukakan bahwa, lingkungan sekolah dapat mempengaruhi sikap siswa termasuk pada kedisiplinannya. Di sekolah, siswa berinteraksi dengan siswa lain, berinteraksi dengan para guru serta pegawai yang berada di lingkungan sekolah. Sikap, perbuatan dan perkataan dari seluruh warga sekolah yang dilihat dan didengar akan dianggap baik oleh siswa hingga tersampaikan ke hati siswa tersebut. ${ }^{15}$

Lingkungan keluarga dan lingkungan sekolah berpengaruh secara signifikan terhadap kedisiplinan siswa kelas IX di SMP Negeri 1 Magetan dengan dibuktikan hasil seperti di bawah ini:

Tabel 5. Tabel anova regresi linier berganda

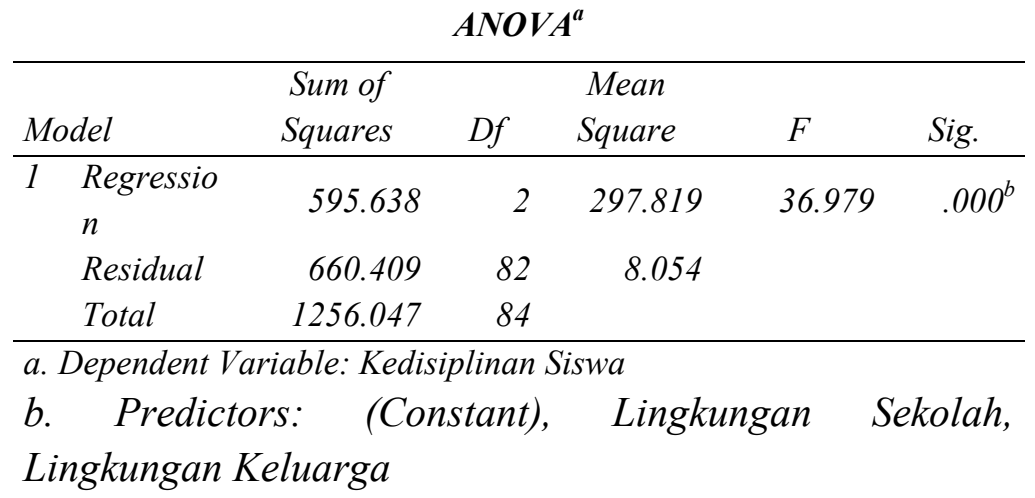

Tabel 6. Tabel model summary regresi linier berganda

\begin{tabular}{lccc}
\multicolumn{4}{c}{ Model Summary } \\
\hline$R$ & $R$ Square & \multicolumn{3}{c}{ Adjusted $R$ Square } \\
\hline $.689^{a}$ & & .474 & .461 \\
\hline
\end{tabular}

a. Predictors: (Constant),

Lingkungan Sekolah, Lingkungan Keluarga

Berdasarkan hasil perhitungan menggunakan rumus regresi linier berganda memperoleh hasil fhitung $(36,979)>$ ftabel $(3,11)$ dengan persamaan regresi $Y$ $=12,453+0,374 \mathrm{X} 1+0,384 \mathrm{X} 2$, maka Ho3 ditolak. Hal tersebut berarti variabel lingkungan keluarga dan lingkungan sekolah berpengaruh secara signifikan terhadap kedisiplinan siswa kelas IX di SMP Negeri 1 Magetan. Besar koefisien determinasi $\left(\mathrm{R}^{2}\right)$ adalah $47,4 \%$ yang berarti bahwa lingkungan keluarga dan lingkungan sekolah memiliki pengaruh hingga 47,4\% terhadap kedisiplinan

${ }^{14}$ Agus Wibowo, Pendidikan Karakter. 54.

15 Kompri. 241. 
siswa kelas IX di SMP Negeri 1 Magetan dan sisa 52,6\% dipengaruhi oleh faktor lain.

Menurut Kompri, adapun faktor yang dapat mempengaruhi kedisiplinan siswa yaitu faktor intern dan ekstern. Faktor intern ialah faktor yang berasal dalam diri siswa, sedangkan faktor ekstern berasal dari luar diri siswa yakni lingkungan keluarga dan lingkungan sekolah. Faktor dari dalam yakni berupa kesadaran diri. Sedangkan faktor yang berasal dari luar diri siswa yaitu pengaruh lingkungan, seperti lingkungan keluarga, lingkungan sekolah dan lingkungan masyarakat. ${ }^{16}$

\section{Pembahasan}

\section{a. Kedisiplinan Siswa}

Disiplin berasal dari bahasa Latin discere yang artinya belajar. Dari kata discere muncullah kata disciplina yang artinya sebuah pengajaran atau pelatihan. Seiring berkembangnya waktu, kata disciplina kemudian mengalami perkembangan makna. Disciplina berarti sebagai latihan yang bertujuan untuk mengembangkan diri supaya berperilaku tertib. Ada juga yang mengartikan bahwa disiplin merupakan sikap patuh terhadap peraturan dalam suatu pengawasan dan pengendalian. ${ }^{17}$

Menurut Tu'u adapun fungsi dari disiplin adalah: menata kehidupan bersama, membangun kepribadian, melatih kepribadian, pemaksaan, hukuman dan menciptakan lingkungan kondusif. ${ }^{18}$ Menurut Syamsu Yusuf juga mengemukakan, keluarga adalah sebuah lembaga yang mempengaruhi perkembangan anak dalam mentaati peraturan khususnya sikap disiplin, bekerja sama dengan orang lain, toleran, menghargai pendapat orang lain, bertanggung jawab dan bersikap matang dalam kehidupan yang heterogen. ${ }^{19}$ Menurut Agus Wibowo, adapun indikatorindikator dari kedisiplinan dapat diuraikan sebagai berikut:

1) Masuk sekolah dengan tepat waktu pada jam yang telah ditentukan sekolah.

2) Mengakhiri kegiatan pembelajaran dan pulang sesuai jadwal yang ditentukan.

3) Menggunakan kelengkapan seragam sekolah sesuai peraturan sekolah.

4) Menjaga pakaian agar rapi dan bersihan sesuai dengan peraturan sekolah.

5) Apabila berhalangan hadir ke sekolah, maka harus menyertakan surat pemberitahuan izin tidak hadir.

17 Ngainun Naim. Character Building. Jogjakarta: Ar-Ruzz Media. 2012: 142.

$18 \quad$ Ngainun Naim. 38-43.

19 Syamsu Yusuf. 40-41. 
6) Mengikuti secara keseluruhan proses pembelajaran secara aktif dan baik.

7) Mengikuti dan melaksanakan kegiatan ekstrakurikuler di sekolah.

8) Mengerjakan semua tugas yang diberikan oleh guru.

9) Melaksanakan tugas piket kelas sesuai jadwal yang ditentukan dengan penuh tanggung jawab.

10) Dapat mengatur waktu belajar dengan baik..$^{20}$

b. Lingkungan Keluarga

Keluarga jika ditinjau dari dimensi hubungan darah adalah kesatuan sosial yang terikat hubungan darah antara satu dengan lainnya. Berdasarkan dimensi hubungan darah, keluarga dibedakan menjadi keluarga besar dan keluarga inti. Sedangkan dalam dimensi hubungan sosial, keluarga merupakan kesatuan sosial yang terikat karena saling berhubungan atau interaksi dan saling mempengaruhi antara satu dengan yang lain, walaupun diantara mereka tidak terdapat hubungan darah. Keluarga berdasarkan dimensi sosial ini dinamakan keluarga psikologi dan keluarga pedagogis. ${ }^{21}$

Dapat disimpulkan bahwa lingkungan keluarga adalah sebuah lembaga pendidikan yang pertama dan utama bagi anak yang sangat berpengaruh pada perkembangan kepribadian dan keberhasilan anak terutama pada sikap kedisiplinannya.

Keluarga memiliki fungsi untuk membekali anggota keluarga agar hidup sesuai dengan nilai-nilai agama yang dianut, pribadi dan lingkungan. Dengan adanya perkembangan dan pendidikan anak, fungsi keluarga harus diterapkan dengan baik dan seimbang. Adapun fungsi-fungsi dari keluarga menurut M. I. Soelaeman yakni sebagai berikut:

1) Fungsi Edukasi

Fungsi edukasi berkaitan dengan keluarga yang menjadi wadah dalam mendidik anak. Dalam fungsi ini yang mendasari yaitu upaya pendidikan, penyediaan sarana, pengayaan wawasan dan lainnya yang kaitannya dengan upaya pendidikan keluarga. Keluarga merupakan tempat pertama dan utama bagi anaknya agar menjadi individu sehat, tangguh, maju dan mandiri sesuai tuntutan perkembangan waktu.

Keluarga menjadi lingkungan yang pertama bagi anak karena tanggung jawab keluarga dipikul oleh orang tua, dan keluarga merupakan salah satu unsur dari tri pusat pendidikan. Orang tua menciptakan pendidikan yang dihayati anak didik sebagai iklim pendidikan dan mengundangnya pada perbuatan-perbuatan yang

20 Agus Wibowo. Pendidikan Karakter. Yogyakarta:Pustaka Pelajar. 2017:100-101.

${ }^{21}$ Moh. Shochib. Pola Asuh Orang Tua Untuk Membantu Anak Mengembangkan Disiplin Diri. Jakarta: PT Rineka Cipta. 2000:17. 
mengarah kepada tujuan pendidikan dengan memberi contoh teladan dan disertai dengan fasilitas yang memadai. Bagi seorang anak, keluarga merupakan tempat pertama yang dikenal dan merupakan lingkungan pertama bagi anak untuk menerima pendidikan. Orang tua secara kodrati langsung memikul tenaga, sebagai tenaga pendidikan, baik bersifat sebagai pemelihara, pengasuh, pembimbing, pembina maupun sebagai guru dan pemimpin terhadap anak-anaknya.

1) Fungsi Sosialisasi

Sosialisasi diartikan sebagai belajar bersosial, dimana anak mempelajari nilai-nilai sosial di lingkungan. Nilai-nilai sosial yang berlaku dalam kehidupan sosial diperkenalkan pertama kali oleh keluarga. Lingkungan keluarga tidak hanya mempengaruhi perkembangan indivivdu, namun juga memiliki kepribadian yang utuh dan berguna bagi kehidupan di masyarakat.

Dengan membiasakan nila-nilai, norma-norma sosial yang berlaku dalam masyarakat merupakan penghubung keluarga dengan anak. Nilai- nilai itu meliputi, nilai dalam kelompok, nilai agama dan nilai kemasyarakatan lainnya. Tempat pertama kali berlangsungnya proses memanusiakan manusia yaitu di dalam keluarga.

2) Fungsi Perlindungan

Keluarga berfungsi sebagai tempat untuk memperoleh rasa aman, nyaman, damai dan tentram bagi seluruh anggota keluarga sehingga kebahagiaan batin terpenuhi, keluarga melindungi anggota keluarganya, memenuhi kebutuhan pangan, sandang dan papan dan sebagainya.

3) Fungsi Perasaan

Pada fungsi ini dapat menunjang keluarga sebagai wadah dalam tumbuh dan kembang rasa cinta kasih sayang antara sesama anggota keluarga dan masyarakat serta lingkungan. Fungsi afeksi diwarnai oleh kasih sayang serta kehangatan yang terpancar dari seluruh gerakan, ucapan, mimik serta perbuatan. Dalam melaksanakan fungsi afeksi, yang terpenting yakni bahasa yang diiringi mimik dapat serasi serta irama yang senada.

Orang tua dapat mencurahkannya melalui interaksi kasih sayang dan kehangatan sehingga memberi suasana keluarga yang harmonis karena saling memberi kasih sayang diantara keluarganya. Kasih sayang dan kehangatan yang diberikan oleh orang tua kalau terlalu berlebihan akan memanjakan anak, sedangkan kalau terlalu kurang akan gersang atau kekeringan. Karena itu, fungsi ini perlu dijalankan dengan proporsional sesuai dengan kebutuhan dan situasi yang dihadapi.

4) Fungsi Religius 
Fungsi religius dapat menunjang keluarga sebagai tempat dalam membangun insan yang beriman dan bertakwa kepada Tuhan Yang Maha Esa, bermoral, berakhlak dan berbudi pekerti luhur sesuai dengan ajaran agama. Dalam melaksanakan fungsi religius, keluarga wajib memperkenalkan dan mengajak anak kepada kehidupan beragama dengan menciptakan iklim keluarga yang religius, sehingga dapat dihayati oleh anggota keluarganya. Tujuan tersebut tidak hanya sekedar untuk mengetahui kaidah-kaidah agama, namun juga menjadikan insan beragama, sebagai hamba yang sadar akan kedudukannya sebagai makhluk yang diciptakan dan diberi limpahan nikmat tanpa henti, sehingga akan menggugah dalam mengisi serta mengarahkan kehidupannya kepada pengabdian Tuhan.

5) Fungsi Ekonomi

Fungsi ekonomi dapat menunjang keluarga sebagai tempat pemenuhan kebutuhan ekonomi, fisik dan materiil yang sekaligus mendidik keluarga hidup secara efisien, ekonomis dan rasional. Fungsi ekonomi meliputi pencarian nafkah, perencanaan serta pemanfaatan dan pembelajarannya.

Pelaksanaan fungsi ekonomi oleh seluruh anggota keluarga mempunyai kemungkinan menambah saling pengertian, solidaritas dan tanggung jawab bersama dalam keluarga, serta dengan segala akibatnya.

6) Fungsi Rekreasi

Dalam menjalankan fungsi rekreasi, keluarga harus menjadikan lingkungan yang nyaman, menyenangkan, cerah, ceria, hangat dan penuh semangat. Dengan melalui kerja sama antara anggota keluarga yang saling mempercayai, menghargai dan mengagumi, mengerti serta adanya "take and give". Keluarga menjadi wahana yang nyaman dan menyenangkan untuk keluarganya, hendaknya menciptakan situasi dan kondisi yang terbebas dari kesibukan masing-masing anggota keluarga.

7) Fungsi Biologis

Fungsi biologis diarahkan untuk menunjang keluarga sebagai tempat dalam menyalurkan kebutuhan reproduksi yang sehat bagi semua anggota keluarga. Kebutuhan biologis merupakan fitrah manusia yang melibatkan fisik untuk melangsungkan kehidupan. Pelaksanaan dari fungsi biologis yakni dengan adanya keseimbangan dalam melaksanakan fungsi-fungsi lain seperti: fungsi religius, edukatif, sosialisasi, proteksi, afeksi dan rekreasi. Keluarga menjadi wahana dalam pemenuhan kebutuhan-kebutuhan dasar seperti kebutuhan keterlindungan fisik, kesehatan pangan, sandang dan papan dengan syarat-syarat tertentu 
sehingga keluarga memungkinkan seluruh anggotanya dapat hidup di dalamnya, sekurang-kurangnya dapat mempertahankan hidup. ${ }^{22}$

Keluarga berperan sangat dominan dalam membentuk kepribadian anaknya. Karakter seorang anak akan terbentuk berdasarkan bagaimana cara keluarganya dalam mendidik. Slameto mengemukakan bahwa faktorfaktor lingkungan keluarga yang dapat mempengaruhi perkembangan perilaku anak seperti: cara orang tua mendidik, relasi antar anggota keluarga, suasana rumah, keadaan ekonomi keluarga, pengertian orang tua dan latar belakang kebudayan. ${ }^{23}$

c. Lingkungan Sekolah

Suwarno menyatakan bahwa, sekolah merupakan lembaga pada bidang pendidikan yang resmi dalam menyelenggarakan suatu kegiatan belajar mengajar yang sistematis, berencana, sengaja dan terarah serta dilakukan oleh pendidik yang professional dengan berbagai program yang dituangkan ke dalam kurikulum tertentu mulai dari taman kanak-kanak hingga perguruan tinggi. ${ }^{24}$

Dapat disimpulkan dari uraian di atas bahwa lingkungan sekolah merupakan lingkungan dengan kondisi di lembaga pendidikan formal, sistematis, dan melaksanakan berbagai program bimbingan, pengajaran dan pelatihan untuk membantu siswa supaya mampu mengembangkan potensi yang dimilikinya.

Beberapa indikator-indikator yang ada di lingkungan sekolah yang dapat mempengaruhi belajar seperti, metode mengajar, kurikulum, relasi guru dengan siswa, relasi siswa dengan siswa, disiplin sekolah, alat pelajaran, waktu sekolah, standar pelajaran di atas ukuran, keadaan gedung, metode belajar dan tugas rumah. ${ }^{25}$

\section{KESIMPULAN}

Berdasarkan rumusan masalah yang peneliti ajukan pada bab pendahuluan di atas, peneliti telah menyelesaikan penelitian dengan pengumpulan data melalui penyebaran angket dan memperoleh hasil, selanjutnya mengubah angket menjadi angka dan melakukan perhitungan menggunakan program SPSS 23.0 dengan acuan rumus regresi liner sederhana dan regresi linier berganda, maka

22 Agus Muharram dan Babang Robandi Uyoh Sadulloh. Pedagogik Ilmu Mendidik. Bandung: Alfabeta. 2018: 188-192.

${ }^{23}$ Enceng Yana dan Neneng Nurjanah. Pengaruh Lingkungan Keluarga Dan Lingkungan Sekolah Terhadap Prestasi Belajar Siswa Pada Mata Pelajaran Ekonomi Di Kelas XI IPS SMA Negeri 1 Ciledug Kabupaten Cirebon. Edunomic 1. 2014: 3.

24 Enceng Yana dan Neneng Nurjanah. 3.

25 Slameto, Belajar Dan Faktor-Faktor Yang Mempengaruhinya. Jakarta:PT Rineka Cipta. 2015: 65-69. 
peneliti memperoleh kesimpulan bahwa: (1) Lingkungan keluarga berpengaruh secara signifikan terhadap kedisiplinan siswa dengan diperoleh hasil nilai $\left(\mathrm{R}^{2}\right)$ yakni 35,3\%, bahwa lingkungan keluarga berpengaruh 35,3\% terhadap kedisiplinan siswa dan sisa 64,7\% ada pada pengaruh faktor lain. (2) Lingkungan sekolah berpengaruh secara signifikan terhadap kedisiplinan siswa dengan didapatkan hasil nilai $\left(\mathrm{R}^{2}\right)$ yakni 32,3\%, bahwa lingkungan sekolah berpengaruh $32,3 \%$ terhadap kedisiplinan siswa dan sisa $67,7 \%$ ada pada pengaruh faktor lain. (3) Lingkungan keluarga dan lingkungan sekolah berpengaruh secara signifikan terhadap kedisiplinan siswa dengan diperolehnya hasil nilai $\left(\mathrm{R}^{2}\right)$ yakni $47,4 \%$, bahwa lingkungan keluarga dan lingkungan sekolah berpengaruh 47,4\% terhadap kedisiplinan siswa dan sisa 52,6\% ada pada pengaruh faktor lain.

Maka dari itu, menurut peneliti ada beberapa saran sebagai berikut: pertama, diharapkan kepada seluruh anggota keluarga terkhusus orang tua dalam proses pembentukkan sikap disiplin anak dapat dilakukan dengan cara memberikan perhatian yang tulus dan memberikan tauladan yang baik sesuai dengan norma agama sehingga dapat menumbuhkan sikap disiplin pada anak sejak dini. Kedua, kepada seluruh pihak yang ada di lembaga sekolah, diharapkan untuk selalu memberikan contoh yang baik dalam pembentukkan kedisiplinan siswa dengan menumbuhkan nilai-nilai positif yang terdapat pada diri siswa. Ketiga, diharapkan supaya siswa mampu menyelesaikan suatu permasalahan yang dapat menghambat proses pembentukkan karakter disiplin dan selalu berusaha dalam melakukan kegiatan yang positif dan lebih disiplin lagi. Keempat, peneliti berharap untuk hasil dari penelitian ini dapat bermanfaat bagi peneliti selanjutnya. 


\section{DAFTAR PUSTAKA}

Agus Wibowo. Pendidikan Karakter. Yogyakarta: Pustaka Pelajar. 2017.

Enceng Yana dan Neneng Nurjanah. Pengaruh Lingkungan Keluarga Dan

Lingkungan Sekolah Terhadap Prestasi Belajar Siswa Pada Mata Pelajaran

Ekonomi Di Kelas XI IPS SMA Negeri 1 Ciledug Kabupaten Cirebon. Edunomic 1. 2014.

Hamzah, B. U. N. L, Tugas Guru Dalam Pembelajaran. Jakarta: PT Bumi aksara, 2016.

Haslinda dan Jamaluddin M. Pengaruh Perencanaan Anggaran Dan Evaluasi Anggaran Terhadap Kinerja Organisasi Dengan Standar Biaya Sebagai Variabel Moderating Pada Pemerintah Daerah Kabupaten Wajo. Jurnal Ilmiah Akuntansi Peradaban 1:8.

Kompri. Belajar Dan Faktor-Faktor Yang Mempengaruhinya. Media Akad: Yogyakarta. 2017.

Moh. Shochib. Pola Asuh Orang Tua Untuk Membantu Anak Mengembangkan Disiplin Diri. Jakarta: PT Rineka Cipta. 2000.

Ngainun Naim. Character Building. Jogjakarta: Ar-Ruzz Media. 2012.

Rusdina, A. Pendidikan Profesi Keguruan. Jakarta: pustaka setia, 2014.

Sadulloh, U., Muharram, A., dan Robandi, B. Pedagogik Ilmu Mendidik. Bandung: Alfabeta. 2018.

Slameto. Belajar Dan Faktor-Faktor Yang Mempengaruhinya. Jakarta: PT Rineka Cipta. 2015.

Sugiarto, A. P, Suryati, T., Yulianti, A. D. Faktor Kedisiplinan Belajar Siswa Kelas X SMK Larenda Brebes. 2019. Vol. 24. No 2:3.

Suyanto. Penelitian Tindakan Kelas. Yogyakarta: Multpress. 2009.

Yusuf, S. Psikologi Perkembangan Anak Dan Remaja. Bandung: PT Remaja Rosdakarya. 